\title{
The Effect of Liquidity According to the Requirements of the Basel III Committee on the Profitability of Banks: Evidence from Saudi Banks
}

\author{
Submitted 03/03/21, $1^{\text {st }}$ revision 02/04/21, $2^{\text {nd }}$ revision 28/04/21, accepted $27 / 05 / 21$
}

\begin{abstract}
Farouq Altahtamouni ${ }^{1}$, Shikhah Alyousef ${ }^{2}$
Abstract:

Purpose: This current study investigates the impact of this new liquidity regulation on banks' profitability in Saudi Arabia. A sample of 12 Saudi banks covering the period 2015-2018 was used in the study.

Design/Methodology/Approach: This study adopted several models of panel data, such as the pooled ordinary least square, the fixed effects model and the random effects model.

Findings: The empirical results indicated that the new liquidity ratio had no impact on Saudi banks' profitability, as it was plausibly illustrated that, when the banks maintained their liquidity levels following application of the Liquidity Coverage Ratio, they would have lower funding costs and risk, hence increasing the banks' profitability.

Originality/Value: This study contributes by investigating the effect of the implementation of the new liquidity standards on the profitability of Saudi Banks.
\end{abstract}

Keywords: Profitability, liquidity, Saudi Banks, Basel III, liquidity coverage ratio.

JEL codes: G20, G28.

Paper type: Research article.

\footnotetext{
${ }^{1}$ Assistant Professor of Finance, Financial Sciences Dept. Community College. Imam Abdulrahman Bin Faisal University, Dammam, Saudi Arabia.

e-mail: fraltahtamouni@iau.edu.sa;

${ }^{2}$ Lecturer of Finance, Financial Sciences Dept. Community College. Imam Abdulrahman Bin Faisal University, Dammam. Saudi Arabia.e-mail: salyousef@iau.edu.sa
} 


\section{Introduction}

The banking and financial sector has a significant role in the global economy (Carey, 2001). Typically, banking institutions have multiple functions, with one being to provide lending services by offering the greatest percentage of their deposits as loans (Mashamba, 2018). However, according to Gorton and Souleles (2007), over the last decade the banking systems have changed and transformed from a traditional banking model into a new form via creating and distributing banking services. By securitization, for instance, banks repackage and provide loans and pass them on to several other financial investors. Due to this transformation, as well as the lending practice, banks' liquidity tends to be affected and may be vulnerable to financial difficulties. In other words, liquidity is essential in maintaining the existence of banks. Hence, irrational decisions about managing the banks' liquidity could lead to a collapse of the financial systems (Gomes and Wilkins, 2013).

In fact, one fundamental reason for the global financial crisis (GFC) in 2008 was that financial institutions experienced liquidity challenges. In other words, they did not have sufficient liquidity to overcome the adverse shocks in that period (Acharya et al., 2011). Consequently, the bankruptcy situation spread over several banks globally, which could characterise this situation as liquidity inadequacy. Naceur et al. (2018) mentioned that the proportion of cash holdings were $17 \%$ of total assets in 2018, while this percentage dropped to below 13\% during the crisis period. Thus, there is a general agreement that the inefficient liquidity management and the liquidity pressure are considered as being the key factors leading to this crisis (Bawazir, 2018).

As a result, it should be highlighted that it is significantly important to regulate the liquidity of banks. The prime function of liquidity regulations is to reduce the frequency and severity of liquidity shocks for banks, to minimize their potential effect on the economy. In response to GFC in 2008, the Basel Committee on Banking Supervision (BCBS) launched the Basel III Accord in 2010. This new framework focuses particularly on capital, requirements of leverage and liquidity, which aim to enhance banks' solvency, impose more stringent standards, and improve the Basel II Accord (BCBS, 2010). In other words, the third edition of the Basel regulation aims to stabilise the banks' liquidity position and contribute to strengthening the global banking sector.

In terms of the liquidity regulation, the BCBS introduced two standards that require banks to hold sufficient high quality liquid assets to cover and survive any liquidity stress situation over a period of 30 days (Mashamba, 2018). Furthermore, banks must ensure that they are able to finance their operations with a stable amount of funding over a one-year period (Gongol and Vodová, 2014). These standards are known as the liquidity coverage ratio (LCR) and the net stable funding ratio (NSFR), respectively. 
More specifically, Hong et al. (2014) explained that the LCR is defined as a ratio of high-quality liquid assets to the total net cash outflows over a one-month period, which contributes to recovering from any significant liquidity pressure. The second standard, namely the NSFR, is considered as a measure of funding stability. It is the ratio of the proportion of available stable funding (ASF) to the required stable funding (RSF) (King, 2013). In general, the purpose of these two ratios is to ensure that banks have appropriate liquid assets and sufficient funding resources over both the short-term and long-term.

Despite the importance of more stringent liquidity regulations in the banking sector, this could potentially affect the performance and stability of banks (Demirguc-Kunt et al., 2008). Hartlage (2012) argued that the LCR and the NSFR tend to weaken the function of the liquidity regulation and contribute to adversely affecting the banking system, as well as the economy. In other words, this extra safety measure might cost banks and pose them higher challenges because of implementing these requirements (Shi, 2018). Banerjee and Mio (2018) noted that, as the LCR is required to hold a large level of high-quality liquid assets, the profitability of banks is likely to be reduced, resulting from low yield earnings. In addition, according to the NSFR's rules, banks might diminish their lending, which could lead to reducing banks' profits from loans, which is considered as an essential source of banks' income (King, 2013).

As a response to the collapse of the global system of foreign exchange the BCBS was established in 1974 (Goodhart, 2011). In this context, the BCBS has, so far, introduced three major global regulations, namely the Basel I, Basel II and Basel III. A brief review of these accords' evolution is provided, as follows.

\subsection{The Basel I Accord}

In 1988 the BCBS introduced the first accord of the Basel regulation, which is a capital measurement system for banks. This accord stresses the case for adequacy of banks' capital (BCBS, 2010). More specifically it was released for banks that have the minimum level of capital to risk-weighted assets of 8\% (Goodhart, 2011). Furthermore, the Basel I requirements aim to avoid any issues regarding credit risk and insolvency.

However, Ahmed and Khalidi (2007) noticed some weaknesses in the framework of Basel I, which led this accord to experience various amendments. Most notably the Basel I worked only as a cushion against credit risk, whereas it should consider the other types of risk, such as operational risk and interest rate risk, when assessing capital adequacy (BCBS, 2010). Another concern raised about implementing the Basel I regulation was the equal treatment of the assets' risk. In fact, each category of assets has a different risk-weight, but the regulation did not consider that issue. 
After several issues emerging regarding the Basel I framework, in 2004 the BCBS introduced the second accord, known as the Basel II (Blundell-Wignall and Atkinson, 2010).

\subsection{The Basel II Accord}

The Basel Committee aimed, with the new accord, to enhance the capital requirements and strengthen the resilience of the banking sector. In addition, this second accord considers the risk management's quality (Balin, 2008). Based on this, the new framework involves three pillars, with the first consisting of a minimum capital ratio for market, operational and credit risks. Accordingly, the operational risk is considered in this new accord as an underlying risk. In line with the first Accord, the minimum capital ratio remained the same as in the Basel I, which is $8 \%$. Moreover, the next pillar was introduced to be the principle of supervisory review, transparency, and risk management guidance. The third pillar is related to the market discipline for banks and is regarded as complementing the former two pillars and the disclosure requirements (Balin, 2008).

However, this second accord has been criticised, especially after the GFC in 2008. Dănilă (2012) mentioned that one of the significant criticisms is that it ignores the leverage and liquidity issues, as it was acknowledged that banks were not adequately prepared for such turmoil. Furthermore, some fundamental risks were underestimated, such as liquidity and credit risks (BCBS, 2010). Consequently, the BCBS accelerated its studies to establish a new and stronger banking regulation.

\subsection{The Basel III Accord}

The Basel II accord failed to prevent the GFC in 2008 and was faced with several criticisms regarding the lack of liquidity monitoring, clear capital definition in the global banking system, etc. Consequently, in 2010, the Basel committee released a new accord, known as the Basel III, to enhance this regulation and its impact on banks. Basically, referring to the BCBS (2013a), the third accord of the Basel framework was designed to deal with liquidity and systematic risks by requiring higher capital and liquidity standards.

More specifically, the three pillars remained the same as in the Basel II; however, there were considerable changes in the first pillar, with two minimum requirements for funding liquidity being introduced and imposed. Notably, these changes regarding the minimum capital standard aimed to raise the quantity of the eligible capital, as well as the quality.

Thus, the main objective of reforming the Basel accord is to improve the ability of the banking sector to absorb any financial shocks and, hence, to diminish their effect on the real economy. Moreover, it is considered that improving the risk management and strengthening the transparency and disclosure of banks have an important role in 
the banking system. Thereby, banks' resilience in the event of a financial crisis would be raised (Petersen and Mukkudem-Petersen, 2014).

In the context of the new rules of the Basel III accord, the minimum capital requirement ratio has increased to $10.5 \%$. In addition to that, a leverage ratio of $3 \%$ has released Tier 1 capital, to reduce the uncertainties from various kinds of risk. Moreover, two liquidity standards have been introduced for the Liquidity Coverage Ratio (LCR) in aiming to improve the short-term liquidity performance of banks. Furthermore, the Net Stable Funding Ratio (NSFR) is the second liquidity standard regarding maintaining a sufficient level of funding (BCBS, 2013a).

\subsection{The Implementation of the Liquidity Coverage Ratio of the Basel III in Saudi Arabia}

The Saudi Central Bank, known as the Saudi Arabian Monetary Agency (SAMA), has pursued efforts to encourage banks to implement the Basel III liquidity requirements (BCBS, 2015). Accordingly, the Basel LCR standards have applied since 2015 via issuing and enforcing the regulations of the SAMA (See Table 1).

Table 1. The Schedule for the LCR Implementation

\begin{tabular}{|l|l|l|l|l|l|}
\hline & $\begin{array}{l}\text { 1 January } \\
\mathbf{2 0 1 5}\end{array}$ & $\begin{array}{l}\text { 1 January } \\
\mathbf{2 0 1 6}\end{array}$ & $\begin{array}{l}\text { 1 January } \\
\mathbf{2 0 1 7}\end{array}$ & $\begin{array}{l}\text { 1 January } \\
\mathbf{2 0 1 8}\end{array}$ & $\begin{array}{l}\text { 1 January } \\
\mathbf{2 0 1 9}\end{array}$ \\
\hline $\begin{array}{l}\text { Minimum } \\
\text { LCR }\end{array}$ & $60 \%$ & $70 \%$ & $80 \%$ & $90 \%$ & $100 \%$ \\
\hline
\end{tabular}

Source: Own study.

In the context of the implementation of the LCR, according to the BCBS's assessment report (2015), a data collection template has been issued by the SAMA to allow each bank to calculate the ratio easily. Furthermore, banks are provided with the required information and technical guidance regarding completing the LCR's computing. In addition, based on that report, the LCR regulation is applicable to all commercial banks in Saudi Arabia on a consolidated level, except for the branches of foreign banks. Currently, there are 12 local banks licensed in the SAMA.

Notably, the SAMA has applied the LCR requirements, except for one item related to the dividing the high-quality liquid assets (HQLA). Overall, the Basel LCR standards have been assessed as being largely compliant with the international Basel liquidity regulations (Table 2).

On the other hand, according to the annual Saudi financial stability report (2019), the LCR has continued to remain stable for the whole banking sector. Hence, it appears that this sector had resilience against short-term liquidity shocks during that period. As shown in Figure 1 below, overall, the Saudi banks' performance is well above the required levels, being about $90 \%$ for 2018 . 
The Effect of Liquidity According to the Requirements of the Basel III Committee on the Profitability of Banks: Evidence from Saudi Banks 444

Table 2. Summary of BCBS members assessments

\begin{tabular}{|c|c|c|c|c|c|}
\hline \multicolumn{6}{|c|}{ Overview of jurisdictional assessments } \\
\hline \multirow[b]{2}{*}{ Jurisdiction } & \multicolumn{5}{|c|}{ Standard and Grade } \\
\hline & $\begin{array}{l}\text { Risk-based } \\
\text { capital }\end{array}$ & $\begin{array}{l}\text { Liquidity } \\
\text { (LCR) }\end{array}$ & $\begin{array}{l}\text { Net Stable } \\
\text { Funding Ratio } \\
\text { (NSFR) }\end{array}$ & $\begin{array}{c}\text { Large } \\
\text { exposure } \\
\text { framework }\end{array}$ & $\begin{array}{c}\text { G-SIB / } \\
\text { D-SIB }\end{array}$ \\
\hline \multicolumn{6}{|l|}{ Argentina } \\
\hline \multicolumn{6}{|l|}{ Australia } \\
\hline \multicolumn{6}{|l|}{ Brazil } \\
\hline \multicolumn{6}{|l|}{ Canada } \\
\hline \multicolumn{6}{|l|}{ China } \\
\hline \multicolumn{6}{|l|}{ European Union* } \\
\hline \multicolumn{6}{|l|}{ Hong Kong } \\
\hline \multicolumn{6}{|l|}{ India } \\
\hline \multicolumn{6}{|l|}{ Indonesia } \\
\hline \multicolumn{6}{|l|}{ Japan } \\
\hline \multicolumn{6}{|l|}{ Korea } \\
\hline \multicolumn{6}{|l|}{ Mexico } \\
\hline \multicolumn{6}{|l|}{ Russia } \\
\hline \multicolumn{6}{|l|}{ Saudi Arabla } \\
\hline \multicolumn{6}{|l|}{ Singapore } \\
\hline \multicolumn{6}{|l|}{ South Africa } \\
\hline \multicolumn{6}{|l|}{ Switzerland } \\
\hline \multicolumn{6}{|l|}{ Turkey } \\
\hline \multicolumn{6}{|l|}{ United States } \\
\hline Compliant & Largely & liant & Materially non-compli & & compliant \\
\hline
\end{tabular}

Source: BCBS, 2015.

Figure 1. The distribution of LCR in Saudi banking sector in 2018

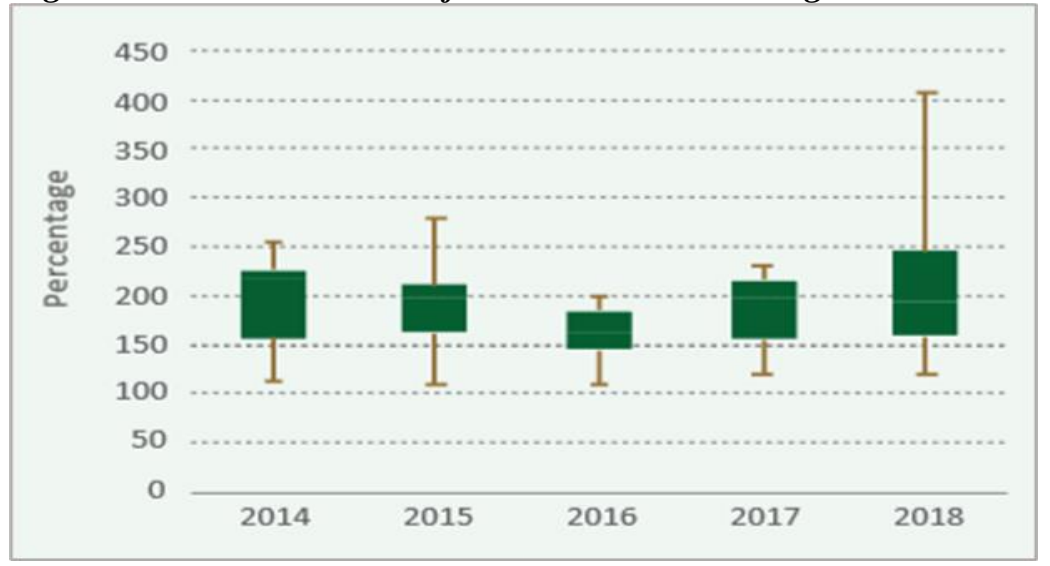

Source: SAMA, 2019. 


\subsection{Research Objectives}

This study aims to:

1- Identify the effectiveness and ability of Saudi banks to implement the Basel III liquidity ratios.

2- Investigate the effect of the implementation of the new liquidity standards on the profitability of Saudi banks.

3- Enrich the knowledge of the Saudi regulators and banks about the liquidity aspect with the expected results and recommendations of this research.

\subsection{Research Question}

Considering the study's objectives, this research aims to answer the following question:

- How do Saudi banks perceive the effect of the new liquidity regulation of the Basel III and its impacts on their profitability?

\section{Literature Review}

\subsection{The Concept and Theories of Profitability}

Profitability in banks means that the ability of generating profits outweigh the costs by considering the capital of the bank (Olweny and Shipho, 2011). In other words, generally, profitability is considered as a relationship between the revenues of banks and the investments that contribute to generating these revenues. This concept tends to lead the banking sector to be more stable and profitable. Alshatti (2015) indicated that this sector would be capable of facing any financial shocks or crises by employing the profitability as an indicator for assessing the banks' adequacy.

According to Lartey et al. (2013), in the past, studies on banks' performance were established by introducing two models for organizations: The Market Power theory (MP) and the Efficiency Structure theory (ES). Furthermore, the portfolio theory has significantly contributed to banks' profitability research (Olweny and Shipho, 2011).

\subsubsection{The Market Power Theory}

Applying the MP theory in the banking sector is defined as the market structure of the sector affecting the performance of banks. For illustration, according to the theory, the concentration level of the banks in the market leads to an increase in banks' market power and, thereby, could raise their profitability. Furthermore, the profitability of banks is affected by the market share. For instance, large banks might be able to influence prices and revenues and exercise the power of the market (Athanasoglou et al., 2008). 


\subsubsection{The Efficiency Structure Theory}

The ES theory, on the other hand, assumes that banks with a high level of efficiency would generate high profits more than others because of lower costs (Owolabi and Obida, 2012). Moreover, banks that have a high market share tend to obtain higher levels of profits, lower costs, rise in the concentration and, thus, profitability. In line with this theory, the portfolio theory is considered as being one of the most important theories for studies of banks' performance. Olweny and Shipho (2011) claimed that this theory posits that the banks' ability to earn higher profits depends on the decisions of the management to hold a feasible set of assets and liabilities. Added to this, the total cost of investments that banks incur is also determined by management decisions. Therefore, there are various internal factors that could determine banks' decisions to gain optimal performance.

Based on the theoretical review above, the ES theory and portfolio theory posit that several internal factors and managerial decisions affect banks' profitability. Additionally, the MP theory largely assumes that banks' performance is influenced by external market variables.

\subsection{The Concept and Theories of Liquidity}

Ibe (2013) explained that liquidity is defined as the capital amount that is enabled to invest it. Bank liquidity refers to banks' ability to hold adequate funds to cover the maturing liabilities. In other words, as illustrated by Olarewaju and Adeyemi (2015), the liquidity of banks is defined as the banks' ability to promptly meet their obligations by holding sufficient funds and being able to convert any assets to cash. Hence, the banks' management of liquidity has the function of maintaining financing sources and holding an appropriate level of short-term money reserves without adversely affecting the banks' investments and profitability.

There are several theories regarding liquidity and liquidity management. One of the fundamental theories is the Trade-off theory. Furthermore, the Liability Management theoryis considered as being an essential theory in this aspect. These theories explained as follows.

\subsubsection{The Trade-off Theory}

This theory states that banks tend to maintain an optimal level of liquidity by creating a balance between the cost and the benefit of holding cash (Alexiou and Sofoklis, 2009). The cost of holding cash, for illustration, consists of a low return on these assets. Furthermore, banks under high leverage or liquidity crises might be unable to obtain debt with a low cost and consequently, these banks' profitability could be affected. In contrast, banks could benefit from holding cash through the availability of funds sources with no need to liquidate assets to pay their obligations. 


\subsubsection{Liability Management Theory}

According to Ibe (2013), this theory assumes that banks could satisfy their liquidity obligations by focusing on both sides of the balance sheet as sources of liquidity. In other words, there is no need for these banks to store a high stock of liquid assets, as they could provide funds from both the capital and money markets.

According to this theory, there is no need to maintain reserves of liquid assets under the availability of capital markets and funds resources. However, this theory has been subjected to critical reviews, specifically during crisis periods. In such as period, confidence in the market might seriously be diminished and, thus, banks would lack funds. Nevertheless, the Trade-off theory assumes that the cost and benefit of obtaining liquid assets depends on various factors, such as the management decisions and reaching the optimal level of liquidity.

\subsection{The Interplay between the Liquidity Coverage Ratio Requirements and Banks' Profitability}

There are far reaching impacts of the profitability performance of banks. In fact, as mentioned previously, the banking system has a highly relevant effect on the whole economy (Pawłowska, 2016). Hence, it is considered that banks' profitability plays a significant role in safeguarding the stability of the economy of a country. Therefore, there is a tendency for national authorities to attempt to improve the profitability of the banking sector and its efficiency.

Alzoubi (2018) and Yao et al. (2018) indicated that banks' profitability has several determinants, such as size, capital, risk, etc. Each variable has a different relationship with profitability. According to the BCBS (2013a), liquidity risk is one of the main kinds of risk that affect banks. Liquidity risk appears when a bank is unable to obtain adequate funds, either by converting assets promptly or by increasing their obligations at an acceptable cost, thus affecting their profitability.

To enhance the management of liquidity risk for banks, the BCBS (2010) introduced the new Base; III liquidity requirements. Although the objective of the new liquidity indicator LCR is to ensure that banks have adequate liquidity to face short-term financial shocks, the feasibility of the Basel III requirements and implementation are widely debated. One strand of the literature argues that liquidity standards have a positive relationship with profitability. In other words, these ratios are likely to decrease the probability of crises and reduce the risk of failures and bankruptcies (Admati et al., 2013; Härle et al., 2010).

However, another strand of the literature indicates that applying the new liquidity requirements could have a significant adverse effect associated with profitability (Angelini et al., 2014). Roger and Vlček (2011) explained that these regulations might lead to raising the stock of liquid assets, which have lower yields, thereby reducing profitability. Moreover, Olweny and Shipho (2011) added that banks 
holding high liquidity could result in incurring opportunity costs that might be generated from investments. Consequently, a high liquidity standard could be an indication that banks are being less risky and less profitable. Therefore, there is a dilemma between profitability and liquidity that banks could face. The following review is based on how banks' performance would respond to the new liquidity standards of the Basel III.

Giordana and Schumacher (2017) studied the profitability of banks in Luxembourg under the implementation of the Basel III liquidity and capital framework. By estimating a historical series of Luxembourgish banks covering the period 2003 to 2011, the study examined the impact of the LCR and NSFR on banks' profitability and probability of default. A Generalised Method of Moments (GMM) system was employed to determine the endogenous relationships between profit, capital, LCR, NSFR and other features. The findings revealed that the new liquidity standards contributed to decreasing the probability of default. Furthermore, the effect of the liquidity standards on profitability was dependent on the funding structure, rather than the assets' structure.

Hong et al. (2014) examined the relationship between the new liquidity standards (LCR and NSFR) and bank failures. They calculated approximate liquidity standards under the guidelines of the Basel III for a sample of U.S. commercial banks over the period 2001-2011. By using a discrete-time hazard model, they found that there was a limited effect of LCR and NSFR on bank failures. In other words, the buffers due to the applying of LCR and NSFR might not mitigate the solvency problem that banks would face at a systematic level.

Using the data of 269 commercial European banks, the study conducted by Roulet (2018) analysed how bank lending responded to the new Basel III liquidity and capital framework. It was considered that loans are the prime source of banks' profitability. This study, which covered the period 2008-2015, used a standard Ordinary Least Squares (OLS) model to provide empirical evidence. Furthermore, the NSFR was considered as a liquidity indicator in the study. It was found that the Basel III liquidity requirements had both a positive and negative effect regarding the characteristics and behaviour of the banks. In other words, although these findings emphasize that, generally, the banks in Europe face pressures to decrease their growth of lending to increase their level of liquid assets following the new liquidity requirements, the commercial lending growth of the banks was positively affected.

Nevertheless, there was an adverse impact on the large European banks following the implementation of the Basel III framework by shrinking their growth of shortterm lending activities. Similarly, King (2013) suggested that the Net Interest Margins (NIM) would reduce by applying the NSFR. In line with previous studies, Banerjee and Mio (2018) empirically investigated the impact of the tighter liquidity regulation on 90 banks' performance in the United Kingdom (UK). The Individual Liquidity Guidance (ILG) was used as a liquidity measure and was introduced by the 
UK Financial Services Authority. In fact, this indicator has a similar design and calculation to the LCR proposed by the BCBS. The results showed there is no evidence to indicate that the ILG implementation had an adverse effect on the banks' lending activity. However, the profitability of banks responded negatively after the application of the ILG, resulting from switching to hold low yield liquid assets. Similarly, Härle et al. (2010) found that the new liquidity regulations led the banks' ratio of Returns on Equity (ROE) to decrease by using a sample consisting of banks in the US and in Europe.

In addition, Saif-Alyousfi et al. (2017) evaluated the profitability of Saudi commercial banks using various parameters. The sample in their study involved 20 domestic and foreign banks in the period 2000-2014. More specifically, the dependent variables were the profitability measures (ROA, ROE and NIM), while the net loans to total deposits and liquid assets to Total assets were used for the liquidity risk measuring. By using OLS and the fixed effect model, the results indicated that the liquid assets to total assets ratio of the domestic banks affected the ROE and NIM negatively.

On the other hand, Mashamba (2018) investigated the effect of the new LCR of the Basel III on the banks' profitability in emerging market economies. The sample in this study included 40 commercial banks over the period 2011 to 2016. A GMM estimator was employed for the data estimation. The dependent variable was ROA for profitability, while the main independent variable was the LCR involved with other control variables. The empirical results showed that the LCR benefitted banks in the emerging markets, including raising their profitability.

Du (2017) tested how the systemic risk of U.S. bank holding companies would be reduced after applying the LCR of the Basel III. The sample period covered 2002 to 2015 and consisted of 761 banks. The study analysed quarterly balance sheets and income statements data to calculate the approximate LCR of the sample. The OLS regression results suggested that the banks would have a lower systemic risk when they have a high level of LCR. The result was proved as it was shown that the banks performed an LCR of below $100 \%$ before the period of the GFC.

The research by Yaacob et al. (2016) examined the liquidity risk determinants using the LCR and NSFR as indicators, in addition to other microeconomic and macroeconomic variables. The returns on assets ratio (ROA), for instance, was calculated as an internal factor to measure the profitability. The sample in this study consisted of 17 Malaysian Islamic banks in the period 2000 to 2013. The two liquidity ratios were calculated following the guidelines of the BCBS and the Islamic Financial Services Board (IFSB) using two models. The regression results showed that the liquidity risk was positively significant to financing. In other words, a rise in financing tends to increase the liquidity risk exposure and, thereby, banks' performance might be affected about an increase of the bankruptcy risk. Therefore, 
an increase in the Basel III liquidity ratios might positively affect the profitability resulting from the minimising of liquidity shocks.

Dietrich et al. (2014) examined the potential impacts of the NSFR under the Basel III on the performance of 921 banks in Western Europe between 1996 and 2010. The study used a regression framework by applying the GMM technique to evaluate how the profitability of the banks responded to the implementation of the NSFR. ROA, ROE and NIM were used as profitability indicators in addition to explanatory and macroeconomic factors. The findings revealed that, before the GFC in 2008, the NSFR generally deteriorated for banks. Additionally, about the effect of the NSFR on banks' profitability, the results showed that banks with a low NSFR performed more volatile. Consequently, it can be suggested that applying the new liquidity indicators tends to lead banks to be more stable and resilient.

In addition, the above findings were supported by Said (2018), who investigated the NSFR effect on the profitability of Malaysian commercial banks. Using a balanced panel data of 8 banks covering the period from 2005 until 2011, the study employed three measures for profitability, namely ROA, ROE and NIM. According to the regression results, the NSFR positively affected all three ratios of profitability. In other words, the banks were able to maintain their profitability's performance, even when switching to holding an HQLA.

Al-Hares et al. (2013) assessed the financial performance of conventional and Islamic banks in the Gulf Cooperation Council (GCC) region under the Basel III standards. The sample included 75 banks covering a period of nine years, from 2003 until 2011. Financial ratios were used to evaluate the banks' performance. More specifically, the study used several ratios to judge the profitability, such as ROA and ROE. Furthermore, the loans to total assets ratio and total loans to deposits ratio were used to assess the liquidity level. The results revealed that the GCC banks tended to be highly sufficiently capitalized, indicating that these banks were in an adequate position to absorb any liquidity stress.

Yan et al. (2012) provided in their paper a long-term cost-benefit analysis for the UK following the new Basel III liquidity and capital requirements. The study's sample consisted of 17 banks for the liquidity assessment, which is considered by the NSFR as a measure for liquidity. Quarterly data from the period 1997 until 2010 was used in this study. In addition to liquidity, the analysis consisted of several microeconomic and macroeconomic variables. The empirical results suggested that the Basel III framework provided a significant positive benefit for the economy of the UK, and it is likely that this benefit will increase when the liquidity requirements are fulfilled and implemented. Moreover, the findings proved that these liquidity regulations played a significant role in absorbing financial crises and increasing the financial stability. 
Overall, the literature review indicates mixed findings regarding the impact of the new liquidity standard LCR on banks' profitability. Some of the studies discussed above noted that this new standard would likely affect the profitability adversely in terms of holding HQLA, which produces low yields. However, others revealed that, with the implementation of LCR, banks would hold more liquidity buffers, thereby reducing the chance of liquidity crises. Therefore, this new regulation tends to enhance banks' financial stability and profitability. Consequently, it is considered that this aspect remains a relatively scarcely researched topic. This current study, therefore, aims to contribute to the existing literature to address this gap. Moreover, the existing studies appear to focus on the effect of the capital and leverage regulations of the Basel III on banks' performance. In contrast, this study is motivated by providing new insights into the contribution of the new Basel III liquidity rule on the profitability of banks.

\section{Methodology}

\subsection{The Data Collection and Sample}

The major sources for this study's data were The Saudi Arabian Monitory Authority (SAMA), The Saudi Ministry of Finance, The Capital Market Authority of Saudi Arabia and The Saudi General Authority of Statistics. The study sample consists of Saudi banks, according to the availability of basic data for the study. Quarterly data for a time of four years, from 2015 to 2018, was considered in this study. Furthermore, this sample period covered the official implementation of the Basel III liquidity ratio in Saudi Arabia.

\subsection{The Study Hypotheses}

Based on previous studies and theories, the main hypotheses of this study to investigate the impact of the LCR on banks profitability are as follows:

H0,1: There is no statistically significant effect of LCR on profitability.

Additionally, the following is a set of hypotheses regarding the control variables:

H0,2: There is no statistically significant effect of size on profitability.

H0,3: There is no statistically significant effect of management efficiency on profitability.

H0,4: There is no statistically significant effect of bank capital on profitability.

H0,5: There is no statistically significant effect of specialization on profitability.

H0,6: There is no statistically significant effect of loan strength on profitability.

H0,7: There is no statistically significant effect of GDP growth on profitability.

H0,8: There is no statistically significant effect of inflation on profitability. 
The following variables will be used to serve the study purposes, as shown in Table 3 below. According to the study question, the profitability of banks is the dependent variable. There are several ratios to measure profitability. The most used ratios to assess the profitability performance are returns on assets (ROA) and returns on equity (ROE) (Mashamba, 2018). The ratio of ROA is calculated as being the net income after tax divided by the total assets, which measures the management's capability to gain profits from utilized assets (Naidu, 2013). However, the ROE is expressed as the ratio of net income after tax to total equity. This ratio indicates how well the banks' ability is to generate profits from equity (Gabriel, 2016).

Based on most of the previous studies, both ROA and ROE were employed in this study to measure the profitability (Saif-Alyousfi et al., 2017; Al-Hares et al., 2013; Said, 2018). These ratios were calculated by using the required information from the balance sheets and income statements.

The main independent variable of interest that assesses the Basel III liquidity regulations is the LCR. This indicator is calculated by dividing high-quality liquid assets (HQLA) by the total net cash outflows (TNCO). Notably, the information about the LCR calculation was provided via the Basel III disclosure reports for each bank, as required by the SAMA. In line with Abreu and Gulamhussen (2013) and Mashamba (2018) this study hypothesises that the LCR diminishes banks' profitability because of the increased holdings of liquid assets, which earn low profits. In other words, the higher the LCR of a bank is, the more high-quality liquid assets the bank will hold. Consequently, the lower its profits would be. Thus, a negative relationship between this variable and profitability would be expected.

In reviewing previous studies on banks' profitability was found that several studies emphasize that several control variables influence the level of profitability. Hence, in this study, the control variables were divided into two categories, namely variables that are bank-specific and variables that are macroeconomic-specific, as follows:

\section{Bank-specific variables:}

\section{A. Bank size (LSIZE)}

Wasiuzzaman and Tarmizi (2010) illustrated that the size of banks is used to assess how size is related to the profitability created by the banks. The size of the bank is measured by taking the logarithm of the total assets. In terms of the effect on profitability, the economies of scale theory suggests that the bigger the banks' size is, the higher the profitability will be, resulting from the lower operating costs and interest rates (Flamini et al., 2009). Therefore, a positive relationship between this variable and profitability would be expected.

\section{B. Management efficiency (COST_INCM)}

The management efficiency of banks reflects the ability of this management to control the operating costs. In following Al-Hares et al. (2013) and Mashamba 
(2018), the management efficiency is calculated as the ratio of operating costs to operating income. This ratio indicates that, if this ratio increases over time, the costs will increase at a higher level than the income and, thus, decrease the profitability (Hussain, 2014). As a result, a negative relationship between this variable and profitability would be expected.

\section{Bank capital (CAP)}

Bank capital is one of the significant variables affecting profitability. This variable provides a source of funding to banks and, thus, it evaluates the capital adequacy. Based on Alzoubi (2018), bank capital is measured as the total equity to total assets. In terms of the relationship between bank capital and profitability, it is suggested that, when the assumption of a perfect market is lightened, a rise in capital would lower the costs related to bankruptcy and financial crises and therefore, banks would be more profitable. In other words, highly capitalized banks are expected to have a low default risk and, in turn, enhance their profitability and creditworthiness (Rao and Lakew, 2012). Hence, a positive relationship between this variable and profitability would be expected.

\section{Specialization (SPEC)}

Loans are the fundamental source of banks' profitability (Borio et al., 2017). Bank specialization is calculated by dividing total loans to total assets (Alzoubi, 2018). According to Mashamba (2018), high specialization in lending leads to banks being able to generate high profits from loans and, thus, increase their profitability. As a result, a positive relationship between this variable and profitability would be expected.

\section{E. Bank liquidity (LOAN_DEP)}

Liquidity ratios indicate how banks can meet their short-term obligations on time. By following Al-Hares et al. (2013), this study assesses banks' liquidity by using the loan-to-deposits ratio. This ratio expresses how much loans have been financed from deposits and, thereby, how this influences profitability. This ratio is measured as total loans to total deposits. In referring to Al-Hares et al. (2013), banks with a higher level of this ratio are considered to have a lower level of liquidity and, consequently, this will increase risk and result in reducing profitability. Therefore, a negative relationship between this variable and profitability would be expected.

\section{Macroeconomic-specific variables:}

\section{A. Economic activity (GDP)}

The Real Gross Domestic Product (GDP) is a significant indicator of the general economic performance of a country (Rao and Lakew, 2012). Furthermore, several papers, such as those of Levine et al. (2000) and Wasiuzzaman and Tarmizi (2010), have demonstrated that the growth rate of GDP has a positive impact on the banking sector. For illustration, if the GDP decreases during a recession, the credit quality will be reduced and, thereby, defaults will increase, hence decreasing the 
profitability. Therefore, a positive relationship between this variable and profitability would be expected.

\section{B. Inflation rate (INF)}

Inflation rate has an impact on the costs and profits of banks and, thus, affect their profitability (Sufian and Habibullah, 2009). In addition, various studies have found that the inflation rate is positively related to profitability (Tarus et al., 2012; Demirgüç-Kunt and Huizinga, 1999). Generally, the inflation rate is associated with a higher interest rate and, therefore, an increase in profitability. However, Vong and Hoi (2009) suggested that the effect of inflation rates depends on the increase of income and costs.

For instance, when income increases more than costs, the inflation rate will positively affect profitability. In contrast, the inflation rate will adversely affect profitability if costs increase more than income. However, in following most studies' findings, a positive relationship between this variable and profitability would be expected.

Table 3. Description of variables

\begin{tabular}{|c|c|c|}
\hline \multicolumn{3}{|l|}{ The dependant variables } \\
\hline Return on assets ROA & Net profit after tax to assets & \\
\hline Return on equity ROE & Net profit after tax to equity & \\
\hline \multicolumn{3}{|l|}{ The independent variables } \\
\hline & Description & The expected effects \\
\hline $\begin{array}{l}\text { The liquidity coverage ratio } \\
\text { LCR }\end{array}$ & HQLA to TNCO & Negative (-) \\
\hline \multicolumn{3}{|l|}{ The control variables } \\
\hline Firm-specific variables & Description & The expected effects \\
\hline Bank size (lsize) & Log (total assets) & Positive $(+)$ \\
\hline $\begin{array}{l}\text { Management efficiency } \\
(\text { cost_incm) }\end{array}$ & $\begin{array}{l}\text { Operating cost to operating } \\
\text { income }\end{array}$ & Negative (-) \\
\hline Bank capital (cap) & Total equity to total assets & Positive (+) \\
\hline Specialization (spec) & Loan to total assets & Positive (+) \\
\hline Bank liquidity (loan_dep) & Loan to total deposit ratio & Negative (-) \\
\hline Macroeconomic variables & Description & The expected effects \\
\hline GDP (gdp) & The growth rate of GDP & Positive (+) \\
\hline Inflation rate (inf) & Inflation rates & Positive $(+)$ \\
\hline
\end{tabular}

Source: The authors.

\subsection{The Empirical Models}

Therefore, the regression models run by E-views software have taken the following forms:

$\mathrm{ROA}_{\mathrm{b}, \mathrm{t}}=\alpha+\beta$ LCR $+\beta$ LSIZE $-\beta$ COST_INCM $+\beta$ CAP $+\beta$ SPEC - LOAN_DEP $+\beta \mathrm{GDP}+\beta \mathrm{INF}+\mathrm{E}$ 
$\mathrm{ROE}_{\mathrm{b}, \mathrm{t}}=\alpha+\beta \mathrm{LCR}+\beta$ LSIZE $-\beta$ COST_INCM $+\beta$ CAP $+\beta$ SPEC - LOAN_DEP $+\beta \mathrm{GDP}+\beta \mathrm{INF}+\mathrm{E}$

where:

- ROA $_{b, t}=$ Return on assets for bank $b$, at time period $t$.

- $\mathrm{ROE}_{\mathrm{b}, \mathrm{t}}=$ Return on equity for bank $\mathrm{b}$, at time period $\mathrm{t}$.

- $\quad$ LCR = liquidity coverage ratio

- $\quad$ LSIZE = Bank size

- COST_INCM = Management efficiency

- $\quad \mathrm{CAP}=$ Bank Capital

- $\quad$ SPEC = Specialization

- LOAN_DEP = Bank liquidity

- GDP = GDP growth

- $\quad$ INF $=$ Inflation rate

- $\quad \alpha, \beta=$ Constant coefficients.

- $\quad \mathrm{E}=$ Idiosyncratic error term.

\subsubsection{Statistical methods used in the study}

To achieve the study objectives, a quantitative method was used in relation to the nature of this study and in line with several papers on the same aspect. There are several models of panel data, such as the pooled ordinary least square, the fixed effects model and the random effects model.

\section{A. Ordinary least square (OLS)}

This model assumes there is homogeneity of all the sections of data in panel data research. That is, each section is similarly treated (Khaldun and Muda, 2014).

B. The fixed effects model (FE)

Alexiou and Sofoklis (2009) explained that this type of panel data model allows for individuality among different cross-sections and, hence, it assumes that each crosssection has its own intercept. Furthermore, the intercept remains the same over time and is correlated with independent variables.

C. The random effects model (RE)

This model allows for heterogeneity and is also time invariant, but the individual specific effect is uncorrelated with the independent variables (Khaldun and Muda, 2014).

To select the best model, the data is tested by the Hausman test (Saif-Alyousfi et al., 2017). In this study the FE regression model was used through E-views software based on the test result, which will be thoroughly explained in the validity section. 


\section{Empirical Results}

The Hausman test was used to determine whether the FE model or the RE model is more appropriate to analyse the data. The hypotheses of this test are as follows.

- $\quad$ Null hypothesis = Random effects model is appropriate.

- Alternative hypothesis = Fixed effects model is appropriate.

According to the test's result, the decision criterion would be to reject the null hypothesis if the probability value is less than $5 \%$, or to accept it if the probability value is greater than 5\% (Alexiou and Sofoklis, 2009).

Table 4. The result of the Hausman test

\begin{tabular}{|l|l|l|l|}
\hline \multicolumn{4}{|l|}{ Correlated Random Effects - Hausman Test } \\
\hline Test cross-section random effects \\
\hline Test Summary & Chi-Sq. Statistic & Chi-Sq. d.f. & Prob. \\
\hline $\begin{array}{l}\text { Cross-section } \\
\text { random }\end{array}$ & 28.4876 & 8 & 0.0004 \\
\hline
\end{tabular}

Source: The authors.

Based on the result above (Table 4), the probability value here was less than 5\% thus, the null hypothesis is rejected and the alternative one is accepted, thereby the FE model was appropriate.

To test for suitability between the FE model and the pooled OLS regression model, the F-test was used (Olweny and Shipho, 2011). This test is known as the Wald test. The null hypothesis of the F-test is that the pooled OLS model is appropriate, which means the data is homogeneous, while the alternative hypothesis is that the FE model is appropriate, which means the study's data is heterogeneous. The null hypothesis would be rejected if the probability value of the Wald test were less than $5 \%$, and vice versa.

Table 5. The result of the F-test (Wald test)

Source: The authors.

\begin{tabular}{|l|l|l|l|}
\hline \multicolumn{4}{|l|}{ Wald Test } \\
\hline Test Statistic & Value & df & Probability \\
\hline F-statistic & 6.9136 & $(7,152)$ & 0 \\
\hline Chi-square & 48.3955 & 7 & 0 \\
\hline
\end{tabular}

Referring to Table 5 above, the decision would be to reject the null hypothesis and accept the alternative; hence, the FE model was the appropriate model.

Table 6 displays the regression results used to test the hypotheses. Although the Fixed Effects (FE) model was the best model for the study's dataset based on the Wald test's result, the results of both the FE and the Pooled OLS models were presented for more explanation. 
Table 6. Regression results of the impact of the Basel liquidity ratio LCR on the banks' profitability

\begin{tabular}{|c|c|c|c|c|}
\hline \multirow{2}{*}{ Variables } & \multicolumn{2}{|c|}{ ROA } & \multicolumn{2}{c|}{ ROE } \\
\cline { 2 - 5 } & Fixed effects & Pooled OLS & Fixed effects & Pooled OLS \\
\hline LCR & $0.000(0.582)$ & $0.000(0.586)$ & $0.004(0.574)$ & $0.000(0.328)$ \\
\hline CAP & $0.238(2.609)^{*}$ & $0.037(5.914)^{*}$ & $0.460(1.330)$ & $-0.228(-5.602)^{*}$ \\
\hline COST_INC & $0.007(0.869)$ & $0.000(0.482)$ & $0.033(0.626)$ & $0.007(0.567)$ \\
\hline M & $0.024(1.097)$ & $0.003(1.054)$ & $0.165(1.144)$ & $0.029(1.207)$ \\
\hline LOAN_DEP & $0.029(3.923)^{*}$ & $0.003(11.017)^{*}$ & $0.201(4.046)^{*}$ & $0.024(11.124)^{*}$ \\
\hline SPIZE & $-0.008(-0.293)$ & $0.008(2.077)^{*}$ & $-0.051(-0.265)$ & $0.066(2.350)^{*}$ \\
\hline GDP & $0.157(5.806)^{*}$ & $0.115(13.398)^{*}$ & $1.094(6.212)^{*}$ & $0.822(14.715)^{*}$ \\
\hline INF & $-0.138(-3.896)^{*}$ & $-0.141(-11.943)^{*}$ & $-0.951(-4.112)^{*}$ & $-0.9626(-$ \\
& & & & $12.517)^{*}$ \\
\hline R-squared & 0.365 & 0.245 & 0.355 & 0.232 \\
\hline F-value & 4.613 & 62.627 & 4.413 & 58.383 \\
\hline
\end{tabular}

Source: Own study.

The key independent variable in this study is LCR, which aims to evaluate the effect of the Basel III liquidity ratio on the banks' profitability. The empirical results indicate that the LCR's coefficient was positive and statistically insignificant at the $5 \%$ level. Thus, evidence could not be found to support the main hypothesis, being that the LCR affects banks' profitability negatively, as a one percent increase in LCR contributes to a $0.41 \%$ growth in profitability. Therefore, in contrast to the widespread belief that the new liquidity regulations of the Basel III would diminish profitability, it was found in this study that the LCR had a positive impact on enhancing profitability. In fact, it could be considered that, based on the Basel committee's aims, the new standards tend to enhance the resilience of banks against any liquidity shocks. Consequently, the null hypothesis is accepted, indicating a positive impact of LCR on banks' profitability.

The FE model results in Table 6 show that the LSIZE appears to be highly positive significant for the two profitability's measures (ROA and ROE). Thus, this suggests that large banks experience higher profits. This positive association is evidence, which is in line with earlier research that suggests that large banks benefit from economies of scale and scope (Zopounidis and Kosmidou, 2008). In other words, a one percent increase in the LSIZE increases the ROA and ROE of banks by 0.0299 and 0.201 , respectively. It should be noted that the coefficient of this variable was inelastic, resulting from the value of that coefficient being below 1. Additionally, 
this coefficient was divided by 100 because of using the logarithm, for it to be consistent with the other variables (Barrow, 2009).

The empirical results show that the coefficient of bank capital (CAP) was statically significant for ROA in both models and for ROE in the Pooled OLS model. However, it was insignificant for ROE in the FE model. This indicates that a $1 \%$ rise in capital leads banks' ROA ratio to increase by about $23 \%$. This result is inconsistent with Hypothesis 4, implying that well-capitalised banks tend to enhance their creditworthiness, subsequently boosting their profits (Flamini et al., 2009).

Management efficiency (COST_INCM) was found to have a positive and statically insignificant effect on banks' profitability in both models. Hence, management efficiency is an unimportant factor affecting banks' profitability. Nevertheless, the coefficient's sign indicates that poor operational efficiency might decrease profitability, and vice versa. Similarly, the loan to deposit ratio (LOAN_DEP) had a positive and insignificant effect on the profitability's measures. This positive impact on profitability was unexpected. However, it indicates that, when banks' deposits increase, new customers and money are added, thereby banks are likely to raise their lending activity and, thus, increase their profitability (Al-Hares et al., 2013). Furthermore, the ideal percentage of this ratio, typically, is between $80 \%$ and $90 \%$. In this study the average of this ratio was $85 \%$, which reflects advanced banks' performance in this aspect.

The variable SPEC was included into the regression model to examine the effect of lending activity on banks' profitability. The study projected a positive impact of this ratio on profitability. Even though the results of the FE model showed a negative insignificant effect of SPEC on the profitability ratios, the Pooled OLS results suggest reverse findings. According to the Pooled OLS results, the SPEC had a positive significant effect on banks' profitability, confirming Hypothesis 5, as a one percent increase in the loan-to-assets ratio contributes a $6.6 \%$ increase in ROE. This result is consistent with the theory of specialization, which states that banks are more profitable when they specialise in traditional lending activity (Kolari and Shin, 2007).

Regarding the macroeconomic variables, the GDP was consistent with our expectation. Both profitability measures were positively significant with GDP growth. An increase of $1 \%$ on economic output translates to a $15 \%$ growth in banks' profitability, which is in line with the conventional wisdom that economic growth enhances bank performance (Mashamba, 2018). On the other hand, the other macroeconomic variable in our model, which is the inflation rate, was in contradiction with our expectation. The results showed a negative significance with both ROA and ROE at the level 5\%. In other words, an increase of $1 \%$ in the inflation rate tends to diminish profitability by about $13 \%$. Yaacob et al. (2016) suggested that, when inflation exists, the interest rate would increase and, 
consequently, might reduce the financing provided by the bank, thereby affecting the profitability.

\section{Discussion}

In line with the purpose of this study, which is to provide an understanding of the effect the liquidity regulation can have on banks' profitability, the following discussion is presented. According to the empirical results displayed in section 4, there was a positive effect of the Basel III liquidity standard on profitability. When the liquidity management of banks enhances their operations' efficiency, the extra costs and risk caused by a lack of funding reduce. Hence, the profitability of banks is enhanced. In line with this result, Giordana and Schumacher (2017) indicated that the liquidity requirements of the Basel III decrease the probability of default for banks. Therefore, banks tend to have lower risk when they have a high level of liquid assets, thus enhancing their stability (Du, 2017; Dietrich et al., 2014). In this context, Yan et al. (2012) and Al-Hares et al. (2013) found that the liquidity regulation played a positive significant role to absorb any financial crises, resulting in increased stability. To illustrate this positive effect, the following discussion is presented.

Firstly, the literature has pointed out that stable banks tend to obtain low costs of funding, as they are recognised to be highly creditworthy (Zopounidis and Kosmidou, 2008). This explanation is consistent with the studies by Yaacob et al. (2016) and Said (2018). As such, the safety and the profitability of banks are likely to be enhanced because of their ability to source cheap financing and to achieve high levels of the Basel liquidity ratio (Mashamba, 2018). This explanation is also supported by the expected bankruptcy cost theory posited by Berger (1995). Bordeleau and Graham (2010) applied this theory to investigate the relationship between the profitability and liquidity of banks. They found that increasing the liquid assets holdings leads banks to have a favourable perception in the markets, therefore decreasing the funding costs and generating more profit.

Nevertheless, this positive result is in contrast with earlier studies, such as Hong et al. (2014), Banerjee and Mio (2017) and Saif-Alyousfi et al. (2017). Based on the Trade-off theory, there is a cost resulting from holding a high level of liquid assets, which generates lower profits compared to fixed assets. Hence, banks' profitability responds negatively to the implementation of the liquidity requirements.

Although the Trade-off theory has been well accepted by most scholars, some have argued that profitability could respond positively by employing efficient liquidity management. That is, even with less profitable assets, holding adequate liquidity tends to prevent banks from high costs, hence having a positive effect on profitability. This explanation is parallel with the Shiftability theory, which is defined as the ability of a bank to manage its liquidity by converting its assets into ready money (Alshatti, 2015). This theory allows banks to hold fewer reserves and, 
conversely, raise investments efficiently by holding assets with a high ability to shift to cash. Under this theory, banks would be able to avoid any liquidity shocks through shifting their assets, as well as increasing their profitability resulting from investments.

In addition, Bordeleau and Graham (2010), after examining the association between profitability and liquidity, found that, if banks' holdings of liquid assets exceed the proper levels, too high levels might lead to inefficiency of the financial and investment operations. This could result in an adverse effect on profitability. This result is consistent with what Roulet (2018) suggested, in that the liquidity requirements had both a positive and negative impact, regarding banks' characteristics and behaviour. Therefore, it is suggested that it is significantly important to achieve an appropriate liquidity level to create a balance between profitability and liquidity.

\section{Conclusion}

After reviewing the results of the study, the key result was that the Basel III liquidity ratio had no effect on the profits of Saudi banks, in other words, bank profits were not affected by liquidity requirements to protect bank funds against risks.

One of the significant concerns raised following the implementation of the Basel III liquidity requirements is their potential undesirable impact on banks' profitability. This impact occurs when banks increase their liquid assets holdings, which generally have low returns and, thereby, could erode the profitability.

\section{References:}

Abreu, J., Gulamhussen, M. 2013. The relationship between capital requirements and bank behavior: A revision in the light of Basel II. Proceedings of the 19th European Financial Management Conference, 23-26 June, Aarhus, Denmark.

Acharya, V., Shin, H.S., Yorulmazer, T. 2011. Crisis Resolution and Bank Liquidity. The Review of Financial Studies, 24(6), 2166-2205.

Admati, A.R., DeMarzo, P.M., Hellwig, M.F., Pfleiderer, P.C. 2013. Fallacies, Irrelevant Facts, and Myths in the Discussion of Capital Regulation: Why Bank Equity is Not Socially Expensive. s.1.: Max Planck Institute for Research on Collective Goods.

Ahmed, R., Khalidi, M.A. 2007. From Basel I To Basel II. Market Forces, 3(3), MF 199.

Alexiou, C., Sofoklis, V. 2009. Determinants of bank profitability: Evidence from the Greek banking sector. Economic Annals, 54(182).

Al-Hares, O., AbuGhazaleh, N., El-Galfy, A. 2013. Financial performance and compliance with Basel III capital standards: conventional vs. Islamic banks. Journal of Applied Business Research, 29(4), 1031-1048.

Alshatti, A. 2015. The effect of the liquidity management on profitability in the Jordanian commercial banks. International Journal of Business and Management, 10(1), 62.

Alzoubi, T. 2018. Determinants of bank profitability: Islamic versus conventional banks. Banks and Bank Systems, 13(3), 106-113.

Angelini, P. et al. 2014. Basel III: Long-term Impact on Economic Performance and 
Fluctuations. The Manchester School, 83(2), 217-251.

Athanasoglou, P., Brissimis, S., Delis, M. 2008. Bank-specific, industry-specific, and macroeconomic determinants of bank profitability. Journal of international financial Markets, Institutions and Money, 18(2), 121-136.

Balin, B.J. 2008. Basel I, Basel II, and Emerging Markets: A Nontechnical Analysis. SSRN Electronic Journal.

Banerjee, R., Mio, H. 2018. The Impact of Liquidity Regulation on Banks. Journal of Financial intermediation, 35, 30-44.

Barrow, M. 2009. Statistics for economics, accounting, and business studies. s.l.: Pearson Education.

Bawazir, H. 2018. Liquidity, liquidity risk and liquidity regulation in banking. s.l.: Doctoral dissertation, University of Southampton.

BCBS. 2010. Basel III: International framework for liquidity risk measurement, standards, and monitoring. s.l.: Bank for International Settlements.

BCBS. 2013a. Basel III phase-in arrangements.

Available at: https://www.bis.org/bcbs/basel3/basel3_phase_in_arrangements.pdf.

BCBS. 2015. Assessment of Basel III Liquidity Coverage Ratio regulations - Saudi Arabia.

[Online] Available at: https://www.bis.org/bcbs/publ/d336.pdf.

Berger, A. 1995. The relationship between capital and earnings in banking. Journal of money, credit, and Banking, 27(2), 432-456.

Blundell-Wignall, A., Atkinson, P. 2010. Thinking beyond Basel III. OECD Journal: Financial Market Trends, (1), 9-33.

Bordeleau, É., Graham, C. 2010. The impact of liquidity on bank profitability, 38. Bank of Canada working paper.

Borio, C., Gambacorta, L., Hofmann, B. 2017. The influence of monetary policy on bank profitability. International Finance, 20(1), 48-63.

Carey, A. 2001. Effective risk management in financial institutions: the Turnbull. Balance Sheet, 9(3), 24-27.

Dănilă, O.M. 2012. Impact and Limitations Deriving from Basel II within the Context of the Current Financial Crisis. Theoretical and Applied Economics, 19(6), 121-134.

Demirgüç, A., Detragiache, E., Tressel, T. 2008. Banking on the principles: Compliance with Basel Core Principles and bank soundness. Journal of Financial Intermediation, 17(4), 511-542.

Demirgüç-Kunt, A., Huizinga, H. 1999. Determinants of commercial bank interest margins and profitability: some international evidence. The World Bank Economic Review, 13(2), 379-408.

Dietrich, A., Hess, K., Wanzenried, G. 2014. The good and bad news about the new liquidity rules of Basel III in Western European countries. Journal of Banking \& Finance, 44, 13-25.

Du, B. 2017. How useful is Basel III's liquidity coverage ratio? Evidence from US bank holding companies. European Financial Management, 23(5), 902-919.

Flamini, V., Schumacher, M., McDonald, M. 2009. The determinants of commercial bank profitability in Sub-Saharan Africa, No. 9-15. International Monetary Fund.

Gabriel, G. 2016. The impact of the Basel III capital requirements on the performance of European banks. (Unpublished Masters dissertation, University de Liege). Available at: https://matheo.uliege.be/handle/2268.2/1837.

Giordana, G.A., Schumacher, I. 2017. An Empirical Study on the Impact of Basel III Standards on Banks' Default Risk: The Case of Luxembourg. Journal of Risk and Financial Management, 10(2), 8. 
Gomes, T., Wilkins, C. 2013. The Basel III Liquidity Standards: An Update. Financial System Review, 37-43.

Gongol, T., Vodová, P. 2014. Liquidity Risk Regulation. Financial Assets and Investing, $5(1), 7-21$.

Goodhart, C. 2011. The Basel Committee on Banking Supervision a history of the early years, 1974-1997. s.1.: Cambridge University Press.

Gorton, G.B., Souleles, N.S. 2007. Special Purpose Vehicles and Securitization. The Risks of Financial Institutions, 549-602.

Härle, P., Lüders, E., Pepanides, T., Pfetsch, S., Poppensieker, T., Stegemann, U. 2010. Basel III and European banking: Its impact, how banks might respond, and the challenges of implementation. EMEA Banking, 16-17.

Hartlage, A.W. 2012. The Basel III liquidity coverage ratio and financial stability. Michigan Law Review, 453-483.

Hong, H., Huang, J.Z., Wu, D. 2014. The Information Content of Basel III Liquidity Risk Measures. Journal of Financial Stability, 15, 91-111.

Hussain, S. 2014. The assessment of operational efficiency of commercial banks in India using cost to income ratio approach. International Journal of Management and Business Research, 4(3), 225-234.

Ibe, S. 2013. The impact of liquidity management on the profitability of banks in Nigeria. Journal of Finance and Bank Management, 1(1), 37-48.

King, M.R. 2013. The Basel III Net Stable Funding Ratio and bank net interest margins. Journal of Banking \& Finance, 37(11), 4144-4156.

Kolari, J., Shin, G. 2007. Assessing the Profitability and Riskiness of Small Business Lenders in the Banking Industry. SSRN Electronic Journal.

Lartey, V., Antwi, S., Boadi, E. 2013. The relationship between liquidity and profitability of listed banks in Ghana. International Journal of Business and Social Science, 4(3).

Levine, R., Loayza, N., Beck, T. 2000. Financial intermediation and growth: Causality and causes. Journal of monetary Economics, 46(1), 31-77.

Mashamba, T. 2018. The effects of Basel III liquidity regulations on banks' profitability. Journal of Governance and Regulation, 7(2), 34-48.

Naceur, S.B., Marton, K., Roulet, C. 2018. Basel III and bank-lending: Evidence from the United States and Europe. Journal of Financial Stability, 39, 1-27.

Naidu, W. 2013. The Implications of Capital Structure theory and regulation for South African banking institutions. s.l.: Doctoral dissertation, University of Pretoria.

Olarewaju, O., Adeyemi, O. 2015. Causal relationship between liquidity and profitability of Nigerian Deposit Money Banks. International journal of academic research in accounting, finance, and management sciences, 5(2), 165-171.

Olweny, T., Shipho, T. 2011. Effects of banking sectoral factors on the profitability of commercial banks in Kenya. Economics and Finance Review, 1(5), 1-30.

Owolabi, S., Obida, S. 2012. Liquidity management and corporate profitability: Case study of selected manufacturing companies listed on the Nigerian stock exchange. Business Management Dynamics, 2(2), 10-25.

Pawłowska, M. 2016. Market structure, business cycle and bank profitability: evidence on Polish banks. Bank i Kredyt, 47(4), 341-364.

Petersen, M.A., Mukuddem, J. 2014. Basel III liquidity regulation and its implications. New York, NY: Business Expert Press.

Rao, K., Lakew, T. 2012. Determinants of profitability of commercial banks in a developing country: Evidence from Ethiopia. International journal of accounting and financial management research, 2(3), 1-20. 
Roger, S., Vlček, J. 2011. Macroeconomic Costs of Higher Bank Capital and Liquidity Requirements. IMF Working Papers, 1-51.

Roulet, C. 2018. Basel III: Effects of capital and liquidity regulations on European bank lending. Journal of Economics and Business, 95, 26-46.

Said, R. 2018. Basel III New Liquidity Framework and Malaysian Commercial Banks Profitability. UKM Journal of Management, 52.

Saif-Alyousfi, A., Saha, A., Md-Rus, R. 2017. Profitability of Saudi commercial banks: A comparative evaluation between domestic and foreign banks using CAMEL parameters. International Journal of Economics and Financial Issues, 7(2), 477-484.

SAMA. 2019. The annual financial stability report., s.l.: Saudi Arabian Monetary Authority.

Shi, Z. 2018. Impact of Basel III on Chinese Firms Access to Credit. s.l.: Doctoral Dissertation, Georgetown University.

Sufian, F., Habibullah, M. 2009. Bank specific and macroeconomic determinants of bank profitability: Empirical evidence from the China banking sector. Frontiers of Economics in China, 4(2), 274-291.

Tarus, D., Chekol, Y., Mutwol, M. 2012. Determinants of net interest margins of commercial banks in Kenya: A panel study. Procedia Economics and Finance, 2, 199-208.

Vong, P., Hoi, S. 2009. Determinants of profitability in Macao. University of Macao working paper, July.

Wasiuzzaman, S., Tarmizi, H. 2010. Profitability of Islamic banks in Malaysia: An empirical analysis. Journal of Islamic Economics, Banking and Finance, 6(4), 53-68.

Yaacob, S.F., Aisyah, A.R., Abdul Karim, Z. 2016. The determinants of liquidity risk: A panel study of Islamic banks in Malaysia. Journal of Contemporary Issues and Thought, 6, 73-82.

Yan, M., Hall, M.J., Turner, P. 2012. A cost-benefit analysis of Basel III: Some evidence from the UK. International Review of Financial Analysis, 25, 73-82.

Yao, H., Haris, M., Tariq, G. 2018. Profitability determinants of financial institutions: evidence from banks in Pakistan. International Journal of Financial Studies, 6(2), 53.

Zopounidis, C., Kosmidou, K. 2008. The determinants of banks' profits in Greece during the period of EU financial integration. Managerial Finance, 34(3), 146-159. 